UDC 159.346.743.652-141.133

DOI: $10.52534 / \mathrm{msu}-\mathrm{pp} .7(4) .2021 .9-19$

\author{
Olha A. Vovchenko* \\ Mykola Yarmachenko Institute of Special Pedagogy and Psychology \\ of the National Academy of Pedagogical Sciences of Ukraine \\ 04060, 9 M. Berlinskyi Str., Kyiv, Ukraine
}

\title{
The Influence of Family Upbringing on the Formation of Self-Esteem of Adolescents with Developmental Disabilities
}

\author{
Article's History: \\ Received: 18.08.2021 \\ Revised: 19.09 .2021 \\ Accepted: 20.10.2021
}

\section{Suggested Citation:}

Vovchenko, O.A. (2021). The influence of family upbringing on the formation of selfesteem of adolescents with developmental disabilities. Scientific Bulletin of Mukachevo State University. Series "Pedagogy and Psychology", 7(4), 9-19.
Abstract. The influence of family upbringing, in particular in particular family archetypes, has an impact on the formation of personality, especially during puberty, affecting various aspects of the mental life, health and behaviour of a teenager, including self-esteem, worldview, vision of one's own "self-concept" in the world. Consequently, the main purpose of the study is to determine special features of the influence of family upbringing on the formation of adolescents with developmental disabilities. In the course of the study, the "KPQAA" method and Dembo-Rubinstein Method of Selfesteem Measurement were used. According to the results of research, it is determined that the leading archetypes of Animus (male aspect of education) are "Warrior", "King", which translate in education not only samples of masculinity (strength, honesty, justice, courage), but also a number of negative aspects, such as rudeness, moral pressure on family members, aggression (physical, verbal, indirect), etc. It is found that the embodiment of the female Anima occurs mainly through archetypal images of "Helen" and "Eve", which indicates the high emotionality of the parenting process, submission as a model for children raised, honesty. It is confirmed that such female archetypes in the process of educating adolescents with developmental disabilities also translate instability of self-esteem, low self-esteem, rapid changes in desires, interests, a tendency to immorality (deception, flattery, betrayal), etc. It is established that the studied adolescents are mainly characterised by inadequately inflated and underestimated indicators of self-esteem, which is a consequence of the influence of leading archetypal images of upbringing in families. The article describes the influence of the style of family upbringing, interaction of parents with children with developmental disabilities on the formation of personality in general and such components as emotional, behavioural, motivational spheres, "self-concept", "self-image", self-esteem, worldview and interaction with modern society. The practical value of scientific work lies in the possibility of further development of effective psychological support for adolescents with developmental disabilities who have problems with the formation of self-esteem

Keywords: an individual with special educational needs, an individual with developmental disabilities, intellectual disability, combined personality development disorders, family upbringing, adolescence, "self-concept"

\section{INTRODUCTION}

Communication is a complex and multi-level process of establishing and developing contacts and connections between people. Quite often, it is included in the practical interaction of the individual. The interest of sociologists, psychologists, philosophers, teachers in the scientific definition of "communication" and its practical comprehension is extremely relevant, since it is closely related to a number of processes that occur with the personality of a child/teenager, 
in particular with special educational needs. The intensity of communication, the variety of its content, goals, and means are the most important factors determining the development of the younger generation: children and adolescents. Only in contact with adults is it possible for children to assimilate the socio-historical experience of humanity and realise their innate opportunity to become representatives of a certain society. This aspect is extremely important for children with special educational needs, who, depending on the characteristics of their psychophysical development, have, firstly, an increased need for communication, openness, perception of their personality by others; secondly, they often need help in establishing the process of communication with the world around them for a number of reasons (physiological features, psychological barriers, psychophysical features, etc.). Analysis of the mental development of a child with special educational needs shows that in the process of complication and development of mental processes, there are naturally different levels of communication between a child and an adult, which replace each other and differ qualitatively from each other. Thus, the development of communication with adults in children and adolescents from birth to adolescence occurs under the conditions of changing several forms of communication.

The most important in the emergence and development of communication is the interaction of an adult, whose proactive initiative is constantly "supporting" the growing personality of adolescents, helping to rise to a new, higher level, based on the principle of "zones of immediate development". Family education should be based on the principles of mutual understanding and mutual respect. For parents, the child or the more mature person (adolescent) is not only an object of upbringing and education, precepts, orders and prohibitions, but above all a separate subject with their own rights and duties, desires, dreams, principles, world view, etc. The family environment combines the personal characteristics of parents, the conditions in which the family lives, the style of upbringing, attitudes and archetypes of upbringing that were passed down from generation to generation. The lifestyle and upbringing of a family has a great impact on the development of a growing person with special educational needs. As T. Kostrykina once noted, family upbringing is carried out in all directions [1]. These are physical, aesthetic, occupational, mental and moral education, which may change as they grow up, but the leading basic principles will remain the same. Such basic principles were defined by K. Yung as "archetypes" [2]. The subconscious, collective knowledge that is transmitted to each of us through everyday habits, stories, traditions, behaviour in everyday life, even through gestures and facial expressions [2]. Therefore, it is obvious that a particular style of family upbringing is based on a certain belief, behaviour style, habits, archetypes and stereotypes of attitudes to the child's personality, in particular to a child/teenager with special educational needs. It is the family attitude and upbringing that shapes adolescents with special educational needs in many ways. Some grow confident, despite their disabilities or certain needs related to health. Others, on the contrary, grow up with low self-esteem, isolate themselves, find it difficult to make contact even with professional psychologists and rehabilitation specialists, withdrawing from the social world of peers and the older generation. Self-esteem is a leading component of the formation of self-awareness of a person with special educational needs. It determines its orientation, the reality of the environment, and determines its mutual influence with other psychological structures of the individual. The family is a social institution that has a large-scale impact on the formation of a person with atypical development and the level of self-esteem formation. Self-esteem from early childhood is formed by the style of family education (archetypes and stereotypes of the family). Low self-esteem does not allow the child's abilities to develop, while too high self-esteem can be dangerous: the child will attribute non-existent advantages and unrealistic prospects to themselves, and then, in the future, may suffer when they encounter a stronger personality or a child with a truly formed self-esteem, or when expectations do not coincide with reality, and so on.

Often, parents have the idea of what an "ideal model" of a child should be, and when it does not meet their dreams, they rebuke their child for it, not noticing the benefits that were simply not included, accounted for in their parenting plans. Therefore, in order for a child not to develop low self-esteem and a sense of inferiority, it is not necessary to place any great hopes on them, so as not to come to disappointment later. Conversely, it is necessary to constantly and carefully notice the benefits, to reveal in the child its inherent features (both positive and negative). Praise and criticism should have a reasonable ratio: everything that a child with special educational needs does cannot be praised unconditionally, but it is also not worth shouting about everything.

If the criticism exceeds the praise, the child/teenager will begin to avoid communicating with their parents or a family representative who does this. And when criticizing a child (if necessary), it is necessary to find what they can be praised for, for example, for independence, for intelligence, the strength of will. In addition, at the end of the conversation, it is necessary to express the sincere hope that the child understands the criticism and will quickly correct everything. Children should be treated especially delicately if there are two or more of them in the family. Because there are parents who openly compare children, put one as an example to the other. Especially if one child does not have any developmental disabilities, and the other is characterised by atypical development. Naturally, this has its mark on the self-esteem of the child's personality, causes feelings of envy, doubts about parental love and outright hostility to the one who is constantly praised. Self-esteem is the difference between real and ideal, and children, especially teenagers, like to create ideals for themselves. Sometimes they want to be like the heroes of books, or now, mostly, the heroes of famous movies, but the problem is that this is often 
unattainable. As a result, the gap between the ideal and the child/teenager is so large that self-esteem falls quite low. This feature is typical mainly for smart, intelligent, knowledgeable and inquisitive teenagers. They are the ones who are most often dissatisfied with themselves and have low self-esteem. Light-hearted teenagers who live in the present day and do not think about the future and do not focus on ideals, mostly do not have problems with self-esteem. Naturally, it is necessary to support the child's desire to move towards the ideal, otherwise, they will grow up to be a self-satisfied and not very educated person. However, first of all, parents need to be able to explain to the child that it is possible to approach the ideal only gradually, through hard work. Explain to the child that if ideals seem unattainable, but they cannot change the real self, then it is necessary to be able to change the attitude in themselves - to the ideal. And, most importantly, it is necessary to convince the child/teenager to love themselves for who they are. Raising a child's self-esteem is one of the most important tasks for their future life and a difficult task in family upbringing. As was already noted, family upbringing style, family values, principles, life priorities, etc. are of great importance in the development of self-esteem.

Therefore, in order to maximise the positive effects and minimise the negative roles of family upbringing and the impact on the child's self-esteem, it is necessary to remember intrafamily psychological factors that are of significant importance:

- two parents to be actively involved in family life;

- always find time to talk to the child (about difficulties in their life, new skills and discoveries, talents);

- not to show any pressure on the child, thus helping to make decisions independently;

- understand or consult with teachers/psychologists about age-related crises in childhood (adolescence);

- respect the child's right to own opinion;

- learn to restrain their own instincts and treat the child as an equal partner who simply has less life experience.

This complex psychological educational process of family education is formed under the influence of many determinants. According to the research of special psychology by V. Zasenko [3], T. Kostrykina [1], L. Marchuk [4], L. Prokhorenko, O. Romanenko [5], I. Chernoshtan [6], researchers' interest in the features and problems of family upbringing styles is growing annually. The number of dissertation studies related to these topics is growing, as is the demand from teachers and parents regarding the particularities of self-esteem formation, especially in younger and older adolescents, are increasing. In practice, psychologists, in particular, often encounter some kind of problem with family upbringing. L. Marchuk notes that now it is quiteoften possible to notice the lack of educational influence of parents and the style of upbringing on the development of the personality of a child, later a teenager [4]. The author claims that the predominant influence on the growing generation, including adolescents with special educational needs, is carried out by teachers and society, that is, the formation of personality takes place outside of "home conditions" [4]. A similar position is held by I. Chernoshtan, who believes that interpersonal relations in the family, in fact, child-parent, have the main influence on the formation of personality behaviour of adolescents outside the family [6]. Therefore, parents do not know what kind of person lives next to them. This often causes family conflicts, misunderstandings, suicides, running away from home and disrupting the adequate mental health of the individual, deforming the psychological structure of the child/teenager, in particular such important aspects as self-esteem and "self-concept". Thus, the purpose of scientific research there is a study of styles, archetypes of family education and their impact on the self-esteem of adolescents with special educational needs (adolescents with special needs are defined as persons with certain psychophysical disorders, in particular intellectual disability and combined disorders (vision, hearing).

\section{LITERATURE REVIEW}

In modern special psychology, the topic of "family upbringing" is most revealed in the research of teachers and psychologists, in particular, it is worth highlighting philosophical and psychological theoretical concepts revealed in the works of such researchers as: A. Leontiev [7], who studied the genetic and structural aspects of the personal content of information transmission; B. Bratus, who proposed the classification of content formations [8]; L. Vygotskiy, who studied the patterns of development of the child's psyche [9]; A. Bodalev [10], V. Lukianenko [11], S. Rubinstein [12], I. Chernoshtan [6], who characterised the ontological relationship between individual and society; A. Petrovskiy [13], who described the structure of personality with special educational needs (developmental disabilities). Also it is advisable to pay attention to the works of psychologists who have studied the features of psychology and the phenomenon of the "archetype" as a well-established image of the vision of the world in particular, the scientific achievements of O. Vovchenko [14], R. Ryan [15], S. Saarni [16], H. Sokolova [17] and others. The study of archetypes as a collective unconscious of a certain group of people, which affects the formation of its structural components, was carried out by such researchers as O. Vovchenko [18], J. Zins and M. Elias [19], V. Kozlov [20]. Special attention in scientific research should be paid to the achievements of the founder of archetypal psychology $\mathrm{K}$. Yung [2]. In addition, the works of modern classics of the archetypal approach in science to personality and its existence in society - O. Donchenko [21], O. Potebnia [22] and O. Romanenko [5] - are important for scientific work. Within the framework of the research topic, it is also necessary to consider the scientific positions of V. Lukianenko, which indicates the genetic features of the transmission of archetypal information to a child/teenager, in connection with which the formation of self-esteem is a genetically determined parenting style passed down from generation to generation [11]. 
Styles of parental education should be studied through the context of Ukrainian researchers G.K. Belgibaeva [23], V. Harbuzov [24], T. Kostrykina [1] and many others. So, for example, H. Sokolova believes that parents, as equal partners in the educational process of a child, choosing and implementing a particular style of the upbringing of a teenager (child), acquire certain "psychological benefits", and the scientist, using the example of the mother, considers two possible options for the relationship of "mother with child" [17]. If the relationship is dominated by the mother, she can accept or reject offers and wishes of the child/teenager, and the child, in response, can support or discuss possible options in a calm tone, make suggestions, justify them, and so on. At the same time, the child will demonstrate "reasonable" submission and act under the protection of the mother, obeying her rules. The benefit of the mother is that she is in charge, the leader, her will is undeniable. If the relationship is dominated by the child, the mother obeys the child's desires, follows the whims of the child/teenager, thus also benefiting by choosing to be a "victim" and relinquishing authority over mistakes made by the child in society (theft, deviant behaviour, etc.). In general, the mother in such relations with the child adheres to the position of non-interference in the problems of upbringing and formation of the future adult personality [17]. V. Harbuzov, emphasising the decisive role of educational influences in the formation of characterological characteristics of a teenager, in particular the formation of selfesteem and "self-concept", identified three types of improper upbringing in the family [24]:

1. Raising rejection, emotional denial - rejection of the child's characteristics or special educational needs related to psychophysical development. Often, parents demonstrate strict control over everyday affairs, in the circle of communication, in addition, it is characteristic to impose their own rules, norms, not listening to the needs or desires, skills or talents of the child.

2. Hypersocialising parenting manifests itself through high expectations of parents from a child with special educational needs. Often, parents show an increased level of anxiety, emotionality, and neuroticism in communicating with families who do not have a child with atypical development. In communication with psychologists, there is complete distrust and rejection of advice and recommendations. Trust exclusively in doctors and rehabilitation therapists. Constant pressure on the child, especially in the field of education, extracurricular activities (additional classes).

3. Egocentric upbringing is characterised by the fact that a child with special educational needs becomes an inviolable personality, a certain type of idol. Any desires are satisfied, indulgence is the norm. Everything is explained by "after all, they are different", "they are unlucky enough as it is", "who will pamper them, if not us/me" and so on.

- Hypoprotection, which is characterised by a lack of guardianship and control. Parents leave such a child/teenager without special supervision or control. There is no special attention paid to the individual, no requirements are put forward, there is no strict control, interest in plans and daily actions. Often such children can be unkempt, untidy, neglected not only on a moral and psychological level, but also on a physical one. Mostly care and control can be described by formal actions of parents, "because it is necessary", rather than by actual desire. Such a family, in particular parents, is not involved in the life, interests, needs, or hobbies of the child/teenager. Consequently, such children/ adolescents are often characterised by antisocial behaviour (delinquent or deviant), as a way to attract the attention of an adult, as an unrealised need for family love.

- Dominant hyperprotection manifests itself through increased, heightened attention, care, excessive guardianship, control in small everyday actions, monitoring the everyday affairs of a teenager, imposing a large number of prohibitions (on communication, buying things in stores on their own, etc.). Parents want to see a teenager mostly busy with academic affairs or just at home, "under control". Such children are not taught from a young age to take independent actions (eat by themselves or undress/dress without the help of others) and take responsibility for their own actions and their consequences. At a more mature age, this contributes to the formation of low self-esteem, lack of initiative, inability to defend oneself and one's interests.

- Indulgent hyperprotection is explained through the creation, indulgence in the process of raising an "idol of worship in the family". In such a family, the child is released from any responsibilities, difficulties, their desires are in the first place, hyper-godliness and overprotection are also characteristic, parents admire minimal success and demand similar attitudes from others. As a consequence, the child develops a high level of ambition, a desire to be the first, to be the leader among others, with a lack of actual strength, skills, knowledge and abilities necessary for this.

- Emotional denial is characterised by the fact that a child/teenager, especially with special needs, is a burden. Therefore, needs are ignored, sometimes abuse is observed, manifestations of general dissatisfaction with the teenager. Often there is a hidden emotional denial: parents tend to hide the real attitude towards the child/teenager with increased care and attention to them. This parenting style has the most negative impact on the development of a child with special educational needs and the formation of personality structures.

- Violent relationships can manifest themselves openly, when the teenager is openly shown negative experiences by all members of the family, sometimes using violence; or be hidden, when there is a certain "wall" of emotional coldness, detachment and hostility between parents and the child.

- Increased moral responsibility is revealed in those aspects when a teenager is required to be honest, decent, and have a sense of duty that does not correspond to their age, psychophysical capabilities (health characteristics, intellectual development). Ignoring the interests and capabilities of the adolescent, put them responsible for the well-being of loved ones $[4 ; 6 ; 18]$. 
G.K. Belgibaeva and V. Stadnik distinguish four types of parental attitude, which forms the self-esteem of a person with psychophysical health disorders:

- acceptable-authoritarian - subjective well-being of parents: a warm attitude and acceptance of a teenager with demands for social success and achievements with control in these areas;

- rejection with aspects of infantilisation and social disability - emotional rejection of a teenager, low value of their individual-characterological characteristics, treatment as to a younger despite their real age, attribution of different types of negative inclinations;

- symbiotic - the desire to establish close, intense emotional contact with a teenager, to participate in all, even fairly small aspects of their life.

- symbiotic-authoritarian - hyperprotection and total control of the behaviour of a teenager's mental life, blocking the realisation of children's dreams, desires, and needs for psychosocial identification [23].

The world practice of psychological assistance to adolescents with special needs and their parents (families, guardians, etc.) shows that even complex problems of upbringing can be solved if it is possible to establish a favourable style of communication and upbringing in the family, identify the leading communication styles, the dominant archetypes of the father and mother. Usually, teenagers learn the patterns of behaviour of their parents and gain confidence in their effectiveness, correctness and the need to apply in life exactly such styles that they remember from childhood. Therefore, the style of family upbringing is imprintedin the psyche of a child, then a teenager as a collective unconscious knowledge and affects the formation of personality in society, in particular, the formation of self-esteem, "self-image". It can also be used as a style of raising one's own children in the future. So, from generation to generation, there is a social inheritance of the parenting style. What K. Yung called the collective unconscious - the "archetype" is deposited in the child's psyche as the norm [2]. This happens unconsciously and when a person grows up, they reproduce this style as natural.

\section{MATERIALS AND METHODS}

Adolescents with special educational needs were considered in this study as those with intellectual disabilities and combined disabilities (sight, hearing). The study included 183 adolescents with intellectual disabilities (according to ICD-10: F70 and combined visual and hearing impairments). Teenagers study in special general education boarding schools of Ukraine: special boarding school No. 26. in Kyiv; special general education school No. 17 in Kyiv (now Educational and Rehabilitation Centre No. 17 in Kyiv); special general education school No. 12 in Kyiv; Centre for Social and Psychological Rehabilitation of Children and Youth with Functional Disabilities of Darnytskyi District of Kyiv; Medical centre "Galchenko Clinic" In Kyiv; Chernivtsi regional educational and Rehabilitation Centre No. 1; Zhytomyr Special School No. 2; Specialised school No. 15 in Kyiv; School of
I-III stages No. 119 in Kyiv; Bila Tserkva comprehensive school of I-III degrees No. 20. Adolescence in the study refers to 11-12 to 16-17-year-olds who were in the institutions in question and whose parents consented to the study. At the same time, parents who agreed to participate in the test were included in the experiment, in particular full and single-parent families, families where grandmothers were in charge of upbringing, or combined families (where there is a mother and grandmother), or families with guardians. The study involved 284 people among families (some parents refused, some parents did not participate - for ethical reasons, we cannot disclose the reasons for refusal). Among the respondents were: 122 - mothers, 109 - parents, 31 grandmothers, 11 - grandparents, 11 - guardians.

The study was conducted in three stages: the first consisted of testing parents, the second stage - testing and psychological diagnosis of children/adolescents, and the third was of a comparative nature (the results of parents and children), recommendations and the formulation of conclusions. It should be noted that recommendations on the style of family upbringing, its change or correction were provided exclusively at the request of the family, and not by force. The study was characterised by a fairly long period of time, as the authors used the rule of "full" demographic sampling, and, as noted, presented different regions of Ukraine, where families and children live.

For the study, the influence of the male and female archetypes on the formation of self-esteem and "self-representation" of a teenager with special educational needs in modern society is important. It should be noted that 161 females and 123 males were covered in this study. The study was conducted using the "KPQAA" method (Kozlov's Personal Questionnaire AnimaAnimus) - a method of studying the deep unconscious "archetype". The "KPQAA" method is a method of studying the transmission of the collective unconscious. Tests for women and men have the same number of questions, but, as mentioned above, they have different questions in content. The test identifies four main archetypes (four female and four male). Each of the four archetypes has a refinement and addition of characteristics in three aspects, so it can be noted that we have 12 archetypal images in detail. The basis for this division is the basic provisions of K. Yung's theory regarding the principles of male and female behaviour, functioning as “... eternal opposites" [2]. The identified archetypes are abstract patterns of personality behaviour and are currently personified in female (Aphrodite, Virgin Mary, etc.) and male (Apollo, Christ, etc.) images The activation of certain archetypes requires certain historical and ethnic conditions. The individual only represents them in their activities (in particular, the upbringing of children and the transfer of basic values and principles of life to them). Detailed analysis (in the process of communication, analysis of the behaviour of certain individuals) makes it possible to identify the leading, dominant archetypes and archetypal features that men and women unconsciously choose as a means of their own identification and transmit to the younger generation that they bring up [20]. The adapted 
method of V. Kozlov is a questionnaire that determines the unconscious attitudes that characterise the types of identification of men and women with different archetypal qualities and roles. The female Anima is revealed through images of Maria, Sophia, Helen and Eva. The male Animus is characterised by the following images: King, Warrior, Lover, and Magician.

The influence on the archetypes and formation of the "self-image of adolescents", in particular on the level of selfesteem, was studied using statistical methods. In fact, adolescent self-esteem was diagnosed and studied by the method of "Dembo-Rubinstein Method of Self-esteem Measurement (modified by A. Prikhozhan)", which helped to characterise the general level of adolescent self-esteem and self-assessment of their own qualities such as intelligence, character and sociability, confidence. The results were evaluated in categories such as inadequately high self-esteem, inadequately low self-esteem, and realistic adequate self-esteem, which included indicators of moderate and high self-esteem. The methodology for adolescents was standardised as a test, so it had the same number of questions and did not differ by gender criterion.

\section{RESULTS AND DISCUSSION}

In the process of diagnosis, using the adapted questionnaire of V. Kozlov, results were obtained that made it possible to determine the unconscious attitudes that characterise the types of identification of men and women with different archetypal qualities and roles, their behaviour in relation to each other, to the process of education and the style of behavioural reactions in society. The female Anima is revealed through images of Maria, Sophia, Helen and Eva. The male Animus is characterised by the following images: King, Warrior, Lover, and Magician. The content and features of the leading archetypes of Anima and Animus according to V. Kozlov [20] can be considered in more detail on the example of the results of the study.

First of all, it is worth noting that according to the results of surveys of women raising adolescents with psychophysical development disorders, it was found that the archetype of Eva and Helen prevails (Table 1). In adolescent boys, the predominant female archetype is Eva (43\%) and Helen (27\%). In adolescent girls - the archetypes of Eve (32\%) and Helen (30\%). This indicates the formation of self-esteem and "self-image" through increased emotionality, empathy, submission, honesty, but at the same time instability of the emotional sphere (short duration of emotional manifestations, rapid changes in desires, interests), a tendency to immorality, if it concerns the achievement of certain desires, goals, the absence of restrictions in their achievements, and so on.

Table 1. Features of the formation of an unconscious Anima archetype in adults ${ }^{\star}$ raising adolescents with intellectual disability and combined disorders (in \%)

\begin{tabular}{c|c|c} 
Leading archetypes & $\begin{array}{c}\text { Female representatives raising } \\
\text { adolescent boys }\end{array}$ & $\begin{array}{c}\text { Female representatives raising } \\
\text { adoles-cent girls }\end{array}$ \\
\hline Maria & 21 & 26 \\
\hline Sophia & 9 & 12 \\
\hline Helen & 27 & 30 \\
\hline Eve & 43 & 32 \\
\hline
\end{tabular}

Notes: * Family, the closest adult environment (mother, father, guardians, grandparents), as described above - those who participate in the upbringing of an adolescent

Based on the data given in Table 1 , it is advisable to consider the features of each individual archetype. Consequently, the archetype "Maria" characterises the behavioural attitudes of women who, according to the results of testing, received the predominant characteristics of this image associated with the idealisation of the role of the mother, who is an educational centre for children, family, protects the genus, family, acts as a centre of order, learning, produces rules in the household. Representatives of the female archetype "Maria" are characterised by centrism on family responsibilities, child care and unconditional love for the child (or for the very idea of a child). The unconscious attitude of women who embody this archetype is sincere, honest service to traditions, submission to the male image, and preservation of traditions. The negative aspect of this archetypal image is the destructive mother's love for the child, firstly, due to the fact that only she (the mother) knows what to do and how to do it; secondly, "all-forgiving", "blind" love for her descendants ("the child is always on top", "they slander them", "my child is the best", "it's not the child's fault, it's..., etc.). Behaviour based on such beliefs often makes a woman a domineering mother (who conquers her husband, but if not, she remains alone and raises children independently, with relatives) or, conversely, a very inert representative in a family where the man is the head of the family, and the woman obeys his rules. The peculiarities of the manifestation of the archetype depend on social traditions, family attitudes (for example, in which archetypes a woman was brought up), the temperament of the man and woman who created a new family.

Turning to the second archetype, namely the archetype of "Sophia", it is necessary to point out that it manifests itself through unconscious attitudes of intellectuality, prudence, feminine wisdom, restraint, morality, and the like. 
Depending on social conditions, these signs have a number of features. Women of this archetype believe that the most important thing for socialisation in modern life is the ability to adapt to the conditions of reality. They are carriers of conservative social and cultural experience, translating moral values, ideals of social behaviour, and so on. Even in the absence of higher education, women with a pronounced archetype of "Sophia", characterised by wisdom, always strive to protect and multiply (for example, to save their family at all costs, always take the side of morality and honesty). As for the attitude to the child, women who embody the archetype of "Sophia" can condemn, scold, punish the child if their act does not meet the norms of morality. The negative aspect of the archetype of "Sophia" is a hyperbolised confidence in the correctness of one's own actions, in how to adhere to traditions, morals, what is right and what is not. So, a woman characterised by such an archetype often restricts other personalities (both adults and children), can slow down the child's development with prohibitions, restrictions, for example, in the process of obtaining the child's own experience/mistakes. Quite often, a woman who is dominated by the archetype of "Sophia" becomes self-serving (financially and socially), self-centred, and ambitious with age.

At the same time, the archetype "Helen" is characterised by such qualities as emotionality and empathy. A woman who has the dominant archetype of "Helen" tends to support, understand, regardless of age, status, material benefits of another person; often encourages, always emotionally empathises with everyone who turns to her, or even just tells about her experiences, problems, and stories from life experience. The destructive characteristics of such a female archetype are emotionality and at the same time - instability of the emotional sphere, short duration and variability of the manifestation of emotions, rapid changes in desires, interests that are transmitted and brought up in the younger generation, which a woman with such a dominant archetype translates into the family. It is worth noting that women with the archetype "Helen" are characterised by hyperbolised perseverance, but negative signs are a tendency to immorality, if it concerns the achievement of certain desired goals, the absence of restrictions in their achievements (treachery, flattery, cunning, slander, betrayal, lies, deception, etc.).

The last female archetype "Eve" is mainly manifested through impulsivity and hypersensitivity. The archetype of the woman "Eve" conveys the belief that "a woman is a man's helper in everything". Women with such dominant archetypes are very submissive to the older members of the family (mothers, fathers, fathers-in-law, mothers-in-law). A woman who translates the archetype of "Eve" into society believes that there must necessarily be a connection, frankness, honesty, trust between a man and a woman, and the main goal is the birth of children. Despite the positive aspects of the archetype, it is important to note that statistically, according to the research of the author of this technique of V. Kozlov, women with this dominant archetype often become persons against whom violence is manifested and carried out [20]. The destructive feature of the Eve archetype is lust, the desire to obtain material goods at any cost, the hyperbolisation of respect for material values in life and status, the need for men's attention, the inability to create security, but still a strong desire for security and stability. The unconscious attitude of the "Eve" archetype is based on desires that must be achieved by any means, while the female body for this archetype is an instrument for achieving material and other types of well-being.

According to the data obtained, after a survey of male representatives involved in the upbringing of adolescents with developmental disabilities, the archetype of Warrior and King prevails. Comparing with the research of representatives of the female group, it is important to note that the clearly dominant male archetypes were quite difficult to identify. Relatively all archetypal images are represented in approximately equal percentage data. In adolescent boys, the predominant male archetype is Warrior (32\%) and King (29\%). Adolescent girls have the archetypes of Warrior (29\%) and King (26\%) (Table 2). This indicates that those archetypes dominate, indicating men characterised by a desire to rule in the family, strongly masculine traits (bravery, strength, confidence), but still translating traits of cruelty, self-confidence, high self-esteem. The lack of self-realisation in representatives of these archetypes outside the family leads to conflicts in the family, the manifestation of abuse toward family members.

Table 2. Features of the formation of the unconscious Animus archetype in adults ${ }^{\star}$ raising adolescents with intellectual disabilities (in \%)

\begin{tabular}{c|c|c}
\hline $\begin{array}{c}\text { Leading archetypes } \\
\text { King }\end{array}$ & $\begin{array}{c}\text { Male representatives raising } \\
\text { adolescent boys }\end{array}$ & $\begin{array}{c}\text { Male representatives raising } \\
\text { adolescent girls }\end{array}$ \\
\hline Warrior & 29 & 26 \\
\hline Lover & 32 & 29 \\
\hline Magician & 17 & 21 \\
\hline
\end{tabular}

Notes: * Family, the closest adult environment (mother, father, guardians, grandparents), as described above - those who participate in the upbringing of an adolescent 
In accordance with the results presented in Table 2, it is advisable to consider in more detail the characterisation of Animus archetypes according to V. Kozlov [20]. First of all, it is worth noting that men who represent the archetype of the "King" are characterised by unconscious psychological attitudes aimed at implementing managerial and organisational inclinations at various levels of manifestation, ranging from domestic to social. Men of this archetype are characterised by such qualities as leadership, the desire for power and managerial positions. Individuals with the dominant archetype of the "King" have a rather flexible character, but are able to show cruelty (in decisions, in behaviour). The negative aspect of representatives of the "King" archetype is excessive self-confidence, high selfesteem, and the belief that power should belong to representatives of the designated archetype, even if the person does not have the necessary qualities (wisdom, strength, leadership abilities, etc.). Such a person will maintain his authority by various means: unjustified cruelty, force (moral pressure, physical means), intimidation, and so on.

At the same time, representatives of the "Warrior" archetype represent unconscious attitudes to struggle, overcoming obstacles, have great strength, honesty, justice, and the desire to fight and defend ideals. The main advantage of the archetypal image is courage, dedication, morality, which representatives of this image consider and translate as the main virtues of a man, as the main necessary qualities of a man. Such men are constantly in a state of confrontation, winning even in small things is important for them. Such a struggle takes place at the domestic level, in the family in relation to the wife or children. The negative aspect of the archetypal image of the "Warrior" is "fighting for the sake of fighting." A person may not have physical or intellectual strength, have many fears, but have high self-esteem. If ambition is not embodied in the professional sphere, then a person who has the features of the "Warrior" archetype will embody their ambitions in the family, punishing family members for their own unrealisation with cruelty, verbal insults, and the like. For the social environment, such individuals will create an ideal image (stories of non-existent exploits, achievements, and family ideality are examples of this).

"Lover" is an archetypal image of a man who seeks to realize life through creativity, the need for love, through the emotional sphere. This direction of feeling often has no objectification (i.e. persona, personality), it can usually be embodied in favourite activities, hobbies, professional activities. Individuals with the dominant "Lover" archetype embody a harmonious combination of strength and compassion, are very passionate, and tend to fall in love with the opposite sex (they prefer to "hunt in relationships", that is, that the object of interest - professional or emotional, was difficult to achieve). The negative aspects of men who embody the archetypal image of the "Lover" are, firstly, inactivity in domestic aspects, a constant state of being in love, daydreaming. Secondly, in choosing a female partner who will embody the image of a mother and take care of such a man, will take care, allowing an adult man to remain in the image of a child, teenager, etc. Third, in the inflated self-esteem of a man and the confidence that a man is the main, weighty, important for society more than a woman, given the fact that he was born a man.

The last male archetype studied is the "Magician" archetype. A man who embodies the image of the "Magician" strives for constant knowledge, search for interesting ideas. Because of the desire to learn about the world and its laws, they are often separated from the real world. They are characterised by detachment, coldness to events occurring in the family, in friendly communication (provided that they are present in the life of a person with the dominant archetype of the "Magician"). In addition, these are people who are prone to manipulation, strive not only for knowledge, but also for obtaining statuses, material benefits, strive to be in the status of the chosen (popular) mainly, not by means of constant creative activity, fruitful work, but by means of cunning, using other persons for their own purposes.

In conclusion, it should be emphasised that the influence of the archetype that prevails in the family in the process of raising a teenager is carried out on a number of factors, including the formation of emotional sphere, self-esteem, self-control, aggressive behaviour, formation of "self-concept". According to the results of the study, it was found that the leading archetypes of male parenting style and representation of norms, rules, behaviour in general are "Warrior" and "King", which demonstrate to the child/teenager both images of masculinity (strength, honesty, justice, courage), and such negative aspects of education as aggression (physical, verbal, indirect), moral pressure on family members, despotism, pedantry, and the like. Female archetypes are represented through the images of "Helen" and "Eve". These archetypes characterise an increased level of emotionality in a woman's behaviour, in the processes of raising her children/adolescents, but also indicate elements of submission and honesty in behavioural reactions towards the male persona and the family as a whole. It should be emphasised that these feminine images are broadcast in the process of educating adolescents with psychophysical development disorders and thus educate: instability of self-esteem, low self-esteem, rapid changes in desires, interests, a tendency to immorality (deception, flattery, betrayal), etc.

A study of adolescents' self-esteem was also conducted. As a result of the study, it was found that adolescents in the transition age period are characterised by inadequately overestimated and underestimated self-esteem indicators. This is a sign, consequence and result of the influence of leading archetypal images of upbringing in the families of the studied: adolescent boys with developmental disabilities characterise themselves mainly by overestimating their self-esteem (47\%), and adolescent girls, on the contrary, underestimate their own importance of self-perception and their self-esteem (46\%) (Table 3). In general, the percentage with realistic self-esteem among adolescents with 
developmental disabilities is not high enough. The average percentage of adolescents with developmental disabilities is $19 \%$ of the total number of respondents with adequate self-esteem.

Table 3. Gender aspect of the state of self-esteem formation of adolescents with developmental disabilities (intellectual disability and combined disorders) according to the methodology "Dembo-Rubinstein Method of Self-esteem Measurement (modified by A. Prikhozhan)" (in \%)

\begin{tabular}{c|c|c}
\hline Adolescent self-esteem levels & Boys & Girls \\
\hline Inadequately inflated & 47 & 32 \\
\hline Realistic adequate & 17 & 22 \\
\hline Inadequately low & 36 & 46 \\
\hline
\end{tabular}

Five main components were also considered separately, which was proposed to be evaluated by adolescents, according to the instructions for the method. Thus, it was found that adolescents with developmental disabilities (intellectual disability and combined disorders) inadequately overestimate themselves in terms of indicators: "intelligence" (46\%), "character" (45\%), "sociability" (63\%) and "popularity" (54\%) (Table 4). Only one of the indicators, in particular "self-confidence", had inadequately underestimated high indicators $-39 \%$.

Table 4. Levels of formation of the main components of self-esteem of adolescents with developmental disabilities (intellectual disability and combined disorders) according to the methodology "Dembo-Rubinstein Method of Self-esteem Measurement (modified by A. Prikhozhan)" (in \%)

\begin{tabular}{c|c|c|c|c|c} 
Adolescent self-esteem levels & Mind & Character & Sociability & Popularity & Self-confidence \\
\hline Inadequately inflated & 46 & 45 & 63 & 54 & 36 \\
\hline Realistic adequate & 35 & 23 & 6 & 9 & 25 \\
\hline Inadequately low & 19 & 32 & 31 & 37 & 39 \\
\hline
\end{tabular}

Note that teenagers realise that they are studying in special educational institutions, they do not consider themselves stupid, unwise. When asked: Why are there so many low grades on the transcript? or Why are there remarks in the diary about not completing homework? adolescents answer that this is due to teacher bias, being busy with household chores or helping their elders at home (with younger siblings), or that "I am not the teacher's favourite"), etc.

Most diagnosed teenagers consider themselves extremely sociable and popular among their peers, other social circles, their acquaintances, and so on. Teenagers note during conversations and interviews that they have a fairly positive, easy-going, affectionate character. In response to comments about fights, quarrels, insults, the use of obscene language against peers or older persons, teenagers, for example, with intellectual disabilities, quite predictably note that this is a provocation, and on their part, it is only a defence of themselves, their boundaries, their neighbours and so on.

According to the results of the experimental study, the interaction and interdependence of the features of the archetypes of education with the level of self-esteem of adolescents with intellectual disabilities was established (Table 5).

Table 5. Summary values of correlations between indicators of emotional, cognitive, behavioural, and motivational components of emotional intelligence (based on the results of an empirical study)

\begin{tabular}{c|c|c|c}
$\begin{array}{c}\text { Self-esteem levels } \\
\text { Types of Anima/Animus archetypes }\end{array}$ & $\begin{array}{c}\text { Inadequately inflated } \\
\text { The archetype of Mary }\end{array}$ & Realistic adequate & Inadequately low \\
\hline The archetype of Sophia & 524 & $774^{*}$ & $554^{*}$ \\
\hline The archetype of Helen & $582^{*}$ & $546^{*}$ & $554^{*}$ \\
\hline The archetype of Eva & $551^{*}$ & 394 & $594^{* *}$ \\
\hline The archetype of King & $598^{* *}$ & 280 & $744^{* *}$ \\
\hline The archetype of Warrior & $774^{*}$ & 340 & $768^{*}$ \\
\hline The archetype of Lover & 290 & $768^{* *}$ & $774^{*}$ \\
\hline The archetype of Magician & 394 & $551^{*}$ & 341 \\
\hline
\end{tabular}

Notes: ${ }^{* *}$ Significance level $\mathrm{p}<0.01 ;{ }^{*}$ significance level $\mathrm{p}<0.05$ 
Summarising the results obtained, it should be noted that no matter how rigid, strange in content, form, style, upbringing in a family environment, collective unconscious experience (collective memory or "archetype") shapes the personality according to collective unconscious ideas. Adolescent accepts them equally and transform them for themselves according to the level of their own development of consciousness, needs, values, formation of abilities, character, etc.

\section{CONCLUSIONS}

The influence of the style of family upbringing, interaction of parents with children with developmental disabilities has significant consequences for the formation of personality in general and such components as emotional, behavioural, motivational spheres, "self-concept", "self-image", self-esteem, worldview and interaction with modern society. The study found that in the process of living in the family, the attitude of family members and general principles of education, which is observed daily by the child, their evaluative judgments are formed about others and oneself. Thus, it is established that mothers of children with special needs mainly raise children based on the attitudes of the two leading archetypes (Eva and Helen), which forms mainly low self-esteem in female children/adolescents, which can manifest itself in self-ignorance, change of desires, obedience, empathy for all, lack of motivation to achieve the goal. In male children/adolescents, such archetypes form inadequately inflated self-esteem and the belief that strength, determination, self-confidence, and arrogance are the best male traits. At the same time, it was found that the leading archetypes among male parents are images of the King and the Warrior. This parenting style indicates a strong, guiding, authoritarian management style in one's own family, where strength is the main proof. Consequently, it is confirmed that in female and male children, such an archetypal parenting style forms inadequate self-esteem. Often, such parents create conflicts in the family, which further distorts the formation of self-esteem in people with developmental disabilities. In addition, it was found that self-esteem is an integral part of the "self-concept". Self-esteem is the knowledge of a child/teenager of themselves and their attitude to themselves, that is, the unity of these two components. It was found that the main factors influencing the formation of self-esteem of children with special needs are the style of upbringing in the family, the evaluative attitude of parents, communication styles and their attitude to the life and activities of the child.

The prospect of further research is to study the influence of archetypes of the Ukrainian ethnic group on the formation of personality, its upbringing, features of psychological assistance or support, etc., including children/ adolescents with special educational needs, since the collective unconscious affects the formation of an adult personality and the process of its socialisation in modern society.

\section{REFERENCES}

[1] Kostrykina, T. (2016). Formation of the "I-concept" of adolescents with intellectual disabilities. Chernihiv: Krytsia.

[2] Yung, K. (1991). Archetype and symbol. Moscow: Izdat.

[3] Lytvynenko, O., Zlatova, L., Zasenko, V., Prokhorenko, L., \& Lunov, V. (2020). Adaptive potential of young people as a factor af mental health-preserving. Journal of History Culture and Art Research, 9(3), 374-385.

[4] Marchuk, L. (2011). Development of the teenager's personality in the conditions of a special general educational institution. Kyiv: Znak.

[5] Prokhorenko, L., \& Romanenko, O. (2019). Features of the classification of objects of the information field of children with delay of psychical development. Information Technologies and Learning Tools, 74(6), 266-277.

[6] Chernoshtan, I. (2015). Family and child: The psychological aspect of child education. Kyiv: Liha.

[7] Leontiev, A. (1959). Problems of mental development. Moscow: Mysl.

[8] Bratus, B., \& Pavlenko, V. (1986). The ratio of the structure of self-esteem and targeted regulation of activity in normal and abnormal development. Voprosy Psychologii, 4, 146-156.

[9] Vygotskiy, L. (1984). Child psychology. Moscow: Pedagogika.

[10] Bodalev, A. (1983). Personality and communication. Moscow: Pedagogika.

[11] Lukianenko, V. (2007). Modern technologies of rehabilitation and training of adolescents with psychophysical disorders. Kyiv: Vydavnytstvo “A\&R”.

[12] Rubinstein, S. (1976). Problems of general psychology. Moscow: Pedagogika.

[13] Petrovskiy, A. (1997). Inappropriate personality activity. Moscow: Gorbunok.

[14] Vovchenko, O. (2019). Social (archetypal) component in the formation of emotional intelligence of children with special needs. American Journal of Fundamental, Applied \& Experimental Research, 2(13), 178-186.

[15] Ryan, R., \& Deci, E. (2000). Self-determination theory and the facilitation of intrinsic motivation, social development and well-being. American Psychologist, 55(1), 68-78.

[16] Saarni, C. (1992). Children's emotional-expressive behaviors as regulators of others' happy and sad states. New Directions for Child Development, 55, 91-106.

[17] Sokolova, H. (2018). Puberty in normal and pathology: Empirical studies. Kyiv: VV Smart.

[18] Vovchenko, O. (2019). The role and importance of archetypalism in the education and upbringing of persons with special needs in Ukraine. Danish Scientific Journal, 30(2), 53-59. 
[19] Zins, J., \& Elias, M. (2007). Social and emotional learning: Promoting the development of all students. Journal of Educational and Psychological Consultation, 17(2-3), 233-255.

[20] Kozlov, V. (2010). New archetypes. Rostov-on-Don: Vitok.

[21] Donchenko, O. (2011). Archetypes - common in our lives (recognition of archetypes as a way to uniqueness). Psychology of Personality, 1, 170-181.

[22] Potebnia, O. (2005). National culture and the process of personality formation. Philosophical Problems of the Humanities, 6, 98-102.

[23] Belgibaeva, G.K., Kenesbeva, S.A., \& Aitzhanova, R.M. (2016). Features of children education styles. International Journal of Experimental Education, 8, 53-56.

[24] Harbuzov, V. (2019). Psychological correction of the relationship between parents and children. Kharkiv: LD DTT.

\section{Ольга Анатоліївна Вовченко}

Інститут спеціальної педагогіки і психології ім. М. Ярмаченка

Національної академії педагогічних наук України

04060, вул. М. Берлінського, 9, м. Київ, Україна

\section{Вплив особливостей родинного виховання на формування самооцінки підлітків з порушеннями психофізичного розвитку}

Анотація. Вплив сімейного виховання, зокрема родинних архетипів, сильно позначається на становленні особистості, особливо в пубертатний період, торкаючись різноманітних аспектів психічного життя, здоров'я та поведінки підлітка, серед яких самооцінка, світобачення, бачення власного «Я-образу» у світі. Відтак, основною метою дослідження є визначення особливостей впливу родинного виховання на формування підлітків із порушеннями психофізичного розвитку. У процесі дослідження використовувались методика «Тест Лока» та методика «Дослідження самооцінки Дембо-Рубінштейн». Згідно з результатами досліджень визначено, що провідними архетипами Анімуса (чоловічий аспект виховання) $є$ «Воїн», «Цар», які транслюють у вихованні не лише зразки маскулінності (сили, чесності, справедливості, хоробрості), а й низку негативних аспектів, як-то грубість, моральний тиск на членів родини, агресія (фізична, вербальна, непряма) тощо. 3'ясовано, що втілення жіночої Аніми відбувається переважно через архетипові образи «Єлени» та «Єви», що свідчить про високу емоційність процесу виховання, покірність як зразок для дітей, які виховуються, чесність. Підтверджено, що такі жіночі архетипи в процесі виховання підлітків з порушеннями психофізичного розвитку транслюють також нестійкість самооцінки, занижену самооцінку, швидкі зміни бажань, інтересів, схильність до аморальності (обман, лестощі, зрада) тощо. Встановлено, що досліджуваним підліткам, переважно, властиві неадекватно завищені та занижені показники самооцінки, що є наслідком впливу провідних архетипових образів виховання в родинах. Охарактеризовано вплив стилю родинного виховання, взаємодії батьків із дітьми з порушеннями психофізичного розвитку на формування особистості загалом і таких їі складових як емоційна, поведінкова, мотиваційна сфери, «Я-концепція», «Я-образ», самооцінка, світогляд і взаємодія із сучасним соціумом. Практична цінність наукової роботи полягає у можливості подальшого розроблення ефективного психологічного супроводу підлітків з порушеннями психофізичного розвитку, які мають проблеми з формуванням самооцінки

Ключові слова: особистість з особливими освітніми потребами, особа з порушеннями психофізичного розвитку, порушення інтелектуального розвитку, комбіновані порушення розвитку особистості, сімейне виховання, підлітковий вік, «Я-концепція» 